\title{
The Influential Effect of Folk Arts - Pot Chitra in Present Trend of Fashion in Bangladesh: An Overview
}

\author{
${ }^{1}$ Najmul Kadir Kaikobad, ${ }^{2}$ Helena Nazneen Zobaida, ${ }^{3}$ Md Zafar Alam Bhuiyan, \\ ${ }^{4}$ Mahmudur Rahman, ${ }^{5}$ S. M. Ashiqur Rahman, \\ ${ }^{1}$ Assistant Dean \& Center Head, Shanto-Mariam University of Creative Technology, City campus, Lalmatia, \\ Dhaka, Bangladesh \\ ${ }^{2}$ Coordinator \& Lecturer, Fundamental of Art \& Design, Shanto-Mariam University of Creative Technology, \\ City campus, Lalmatia, Dhaka, Bangladesh \\ ${ }^{3}$ Assistant Proctor \& Lecturer of Fashion Design, Shanto-Mariam University of Creative Technology, City \\ campus, Lalmatia, Dhaka, Bangladesh \\ ${ }^{4}$ Lecturer, Fundamental of Art \& Design, Shanto-Mariam University of Creative Technology, City campus, \\ Lalmatia, Dhaka, Bangladesh \\ ${ }^{5}$ Senior Motion Graphics Designer,Desh TV, Dhaka, Bangladesh
}

\begin{abstract}
Recognizing Pot Chitra as formalized folklore, the word Pot Chitra has been analyzed. The customs of picture painting and the making of elongated Pot Chitra have been discussed. Amongst the thousands of materials or objects in the folk arts it is not difficult to understand the worldly characteristics. Sometimes, the divine philosophies and the realistic philosophies have been the guide amongst these topics. The formation of art and its rhythmic outlines were attained by the artist's aesthetic mind. Therefore, the mass, volume and types of art-forms can be found, such as, pottery, carpentry and engraving, architecture, metal crafts, shell crafting, ivory crafting, mask making etc. Similarly in the graffiti, quilt-making, mat-crafting etc, and even in the ornament craft, the aesthetic rhythm of art is evident. Folk art, the integrated part of Bengal, displays a rich vocabulary of motifs. These motifs are deeply rooted in strong religious beliefs and underlay a strong symbolism. These motifs signify the desire for "self expression" and manifestation of the artisan's aspirations.
\end{abstract}

\section{Introduction}

Fashion in Bangladesh is growing and becoming increasingly fruitful in its endeavors. More and more designers are popping up, making an effort to bring the industry up to international standards. In the process, however, it is sad to say that, in many cases, the glamour and glitter of other, more advanced industries around the world, such as India, influence our fusionist designers as so much that we often lose our own sense of fashion and merely follow the trends set by others. Being India as a neighboring country is hard for Bangladesh's self image. As it is, we tend to measure our success according to the success of the Indians, never taking into account that they are far older as a nation. In addition, we look to India for trend in many different aspects of our daily lives, be it arts, music, entertainment or even fashion. Let's not be denied the fact that many Bangladeshi women and girls or boys are quite happy trying to look like the latest Bollywood actress or actor. In fact, how many times have one walked into a sharee store and had a chumki-ala, shaded sharee thrown in one direction, claiming it was the latest thing in India, even naming it after the movies in which beautiful doll-like actresses with impossibly thin figures wear. We constantly fall into the trap of idealizing everything the Indians do. Those who can afford to do so always go to India for wedding shopping, rather than doing any major shopping in Bangladesh. And already there are a handful of big stores in the Gulshan area which strongly look like shops in India. Rather than taking pride in what sets us apart from other nation: our culture, our traditions and our heritage. We spend all our time copying Indian trends while we slowly lose our own sense of style. Gone are the days of Tangail Handloom and Jamdanis, because Bollywood has not thought them worthy of glamorizing. Our designers have no choice but to keep bringing in more Indian trends in order to keep their clients happy.

Our analysis is about Bangladeshi fashion design deals only with the surface such as block, batik, embroidery, hand paint etc. These aspects are very strong in the fashion industry, but unfortunately surface work is only a part of designing. There are many different aspects that are not touched upon as much as they should be here, such as fittings, patterns or even forecasting and also the relevance of what works with our surroundings. For example, many people don't distinguish that the colors and fabrics that are relevant for summers; for an example mainly light colors and fabrics that breathe - are not necessarily relevant for other seasons, such as winter, in which designers can use darker colors and more heavy fabrics. Using handloom fabrics that are both 'colorful and cultural,' we feel that we can create design such as depict the innocent and pure beauty of the indigenous community of Bangladesh. 
We believe in this research work will prove that our country is so rich, but we just don't understand it or know about it. There are so many opportunities for us and we have a variety of things to choose from, but we do not take advantage of what we have. We are surrounded by so many cultures that can contribute to fashion such as Pot Chitra.

Pot Chitra is a kind of folk arts. Identifying Pot Chitra as formalized folklore, the word Pot Chitra has been analyzed. The customs of picture painting and the making of elongated Pot Chitra have been discussed. The Pot Chitra was classified to the contexts. Some primitive processes of making brush and the ink exist which are very own of the Potuas. The processes vary in different districts. In some cases there are some similarities as well. There are a number of different patterns and bright colors in Pot Chitra that we can use and bring into the mainstream market in order for people to see what we have. In this research paper, we try to show the fusion of stylish fittings and traditional patterns merged into an interesting blend which symbolizes the strength of a fashion industry that wants to hold onto its roots but at the same time move forward.

In addition, our local boutiques design also reminds us that there are many aspects of Bangladesh that the majority of us have not explored or educated ourselves about. We constantly look into the other nations for reassurance and acceptance, all the while not promoting and taking pride in the beauty that we have within our grasp. While these designs are western patterns, at least it is important that we are supporting these forgotten cultures by showcasing their worth and bringing them out of the shadows that they have been hiding under for far too long.

\section{Glossary Of Terms}

- Pot Chitra: "Pot" means "scroll" and "Chitra" means Painting

- Potua: "Potua" or "Chitrakar" means "Painter".

- Tangail Hand Loom: One types of Bangladeshi Hand Loom

- Jamdanis: One types of Bangladeshi Hand Loom

- Chumki-ala: Name of Boutique Shop

- Gazi : Victor

- Gazir Pot: One types of Scroll Painting of South-West Bangle (Part of Bangladesh \& India)

- Kalighat Pot: One types of Scroll Painting of West Bengal (Province of India)

- Gayen: Lead singers or narrators of Scroll Painting

- Puranic: Mythological

- Pala Gaan: Live Drama

- Slokas: Mythological Folk stories

- Sabitri-Shottoban, Ram-Sita-Rabon and Korno: Characters from Ramayan and Mahabharat

- Sutrodhar: Carpenter

- Malakar: One type of Artisans who create handy crafts by using paper, one type of soft tree locally called 'Shola' etc.

- Chumki-ala: One type of Surface Design

- Sharee: Bengali traditional costume for women

- Bollywood: Film city of India

- Bratachari camp:

- Guru Sadoy Dutta: He was a eminent civilian who oganize Bengole movement colled Bratachari movement.

- $\quad$ Bratachari movement: Bengali National movment

- Shakher Nandi: urn-shaped pot of capricious inclination

- Alpona: Design by Bengali folk motif

- Pata-chitra: One types of Pot Chitra

- Janmashtomi: Birth day of Sri Krishna (Spiritualist of Hindu Religion)

- $\quad$ Shetal Pati: One type weave mat

- $\quad$ Bel: Wood Apple

- Lokkhi: Goddess of Hindu Religion

- Dhotis / Lungis: Bengali traditional costume for men

- Arshilota: A narrow embroidered wrapper to roll and store away a woman's comb, mirror, eye kohl, vermilion, sandal paste, oil bottle, etc.

- Ashon: One type of mat

- Batwa thoiley:

- Ghilaf: Arabic word also Cover

- Jainamaz: Mats used by Muslims to say prayers

- Galicha: Floor covering 
- Bostani, guthri: A square wrapper for books and other valuables

- Dhakni: Covering cloths of various shapes and sizes

- Daster khan: A spread for eating place, used at meal time

- Balisher chapa or Oshar - A flat single piece pillow cover

- Rumal: Handkerchief - Small and square in shape

- Ekushey: $21^{\text {st }}$ of February which is calibrate as International Mother Language day

- Taaga: Thin cotton thread used by village women, children to hang something with neck, waist, and arms

- Panjabis: Bengali traditional costume for men

\section{Literature Review}

For our research we have choose primary and secondary sources to collect the data. We have made through study books like Banglar Lokoshilpo by Dr. P. Ghosh, Proshango: Pot, Potua o Potua Shangeet by Dr. C. Mayti, Gagir Gan: Shilpo Riti by A. Ahmed, Potua Roghu Nather Shilpo Bhubon by D. Hosson, Openti Bioscope by S. Shom, Bangalir Attoporichoy by Mustafa N. Islam, Banglar Lokonattao Palagan: Prokriti o Proyog by Raji. A. Alim, Foklor Shangrohosala by Shahed M. Sayed, Shanskritik Oaytijha Abong Nrittoshilpor Bistar by K. Lohani, Banglar Loko Shanskriti by W. Ahmed and other related books. More information was gathered from 'Openti Bioscope' where detailed description is given about Bengali Folk Art like Pot Chitra. This book was very helpful in providing in depth explanations and references of other designers who will know the details information about Pot Chitra.

A. Patua Quamrul Hassan

Quamrul Hassan (1921-1988) occupies the most distinguished place in Bangladesh's fine arts after master artist Zainul Abedin (1914-1976). His creative talents were multifaceted and his art works are characterized by constant reinvention and experimentation. His continual experimentation also facilitated a better understanding of the various media and their potential. Besides familiarity, this also gave him a facile competence in and control over diverse forms and expressions of art. A natural affinity for tradition lies at the heart of Quamrul's aesthetics. He has been eminently successful in blending the folk with the modern, the indigenous with the western - creating a modern diction that retains its links to indigenous forms and expressions sustained over centuries. His works are distinctive because of this matchless blending of the arts and styles of the East and the West. There has been an additional embellishment at times by a measured touch of Chinese art, profound in the heart of his hearts, Quamrul was passionately engaged in the pursuit for beauty all through his life. This is best celebrated in the portrayal of the Bengali women and the vitality of feminine beauty in his works. Quamrul Hassan has also been deeply committed to his roots and the social responsibility born of this sense of belongings. He has been closely associated with the progressive inclination in politics. Nationalism, devotion and a tremendous sense of the present and of worldliness were strong in him. He has never diverged away from the quest of humanism and the Bengali inheritance. He was against all forms of ignorance and backwardness and was convinced in the progressive values of mankind. All through his life, he has been a free intellectual.

The folk-rootedness in Quamrul was not a exterior thing; it was a heart element of his inspirations. His sense of heritage was engraved deeply in his attitude towards life and his own philosophy. As a result, elements of myths have greatly prejudiced his works. This would be abundantly clear from a close study and analysis of his works, the assemble of his forms and figures, the choice and use of colours and lines as well as the nuances he weaves into them. A sequential approach would help identify some of the sources of Qamrul's passion for the folk.First, it would be recalled that Quamrul Hassan participated in a month long Bratachari camp (December 1939) a year after he got admitted into Kolkata Government Art School (July 1938). Guru Sadoy Dutta's (18821941) Bratachari movement was started with a view to re-establishing the glorious heritage of Bengalis as a rejection of and expression of resistance against British colonial rule. Quamrul Hassan was so influenced by the ideas of this movement that he continued to hold on to these ideas until his last days. It was here at the Bratachari camp that he came across potuas and the traditional potua artists of Bengal. He learnt about the significance of this age-old art form from Guru Sadoy Dutta. He was attracted by the style, especially the use of basic colours, methods of drawing figures in profile, the inherent, two-dimensional features, the unprompted nature of lines etc. Quamrul Hassan used all these features in his own works. He entered a pata painting in the Muslim Art Exhibition in 1946 for the first time. We find various motifs and expressions of folk art entering his world of art form of dolls, birds and fishes from Rajshahi's shakher Nandi (urn-shaped pot of capricious inclination), the 'evil' owl, fox, snake, crocodile, lizard, or vultures etc. parallel to "beauteous and innocent" animals like peacocks, chicken, cows, horses, elephants, turtles, cats, storks and goats. Keeping in mind these three sources, one may proceed to analyze the nature and extent of the folk affinity in Quamrul Hassan. It is clear that he has drawn elements, both of style and substance, from the folk arts, but his works are not overtly folk. Quamrul Hassan did not forget even for a moment nor did he allow us to forget that he was a modern artist, 
not a folk craftsman. For this reason, elements and features of the folk have blended with modern western styles in his paintings with such fascinating competence. Quamrul Hassan has achieved a distinguishing expression in his art and his aesthetic vision through a blending of these two trends.

\section{B. Potua Shambhu Acharya:}

Potua Shambhu Acharya was discovered by the researcher Dr. Tofael Ahmed from Munshigonj after his (Dr. Tofael Ahmed) visit in Kolkata Museum. Being an inspired person as a researcher Dr. Tofael Ahamed reveled the talent Potua Shambhu Acharya and his family which has a virtually successful tract in creating Pot Chitra in his style. Potua Shambhu Acharya is the $9^{\text {th }}$ generation of his family tree who are traditionally artist from inner inspiration transpiring from the generation to generation. He is skilled and self sufficient with his creation, using different media to draw his Pot Chitra in the coarse canvas. His creation is different from others as he claims that he is fond of beautifulness from the elements or factors of his drawing. Potua Shambhu Acharya is merely not a Potua but a researcher of his time which could be claimed to the living treasure of folk arts. Folk singers collect the Pot Chitra from him and spread to the rural and urban areas of Bangladesh as their predecessors did in the past. He is living source of inspirations and creation a new arena in this age bridging with the past and future.

\section{Potua Raghunath Chakroborty}

Pot Chitra or story telling through depicting images on canvas has always been a traditional form of art and entertainment. The trail goes a long way back to the Middle Ages when story telling was an important form of entertainment in Bengal. Poets told tales of gods, saints and the virtuous, of kings and queens, through their writings. Artist's portrayed these verses through colors and motifs. The age-old folk art survived centuries to tell the tales. It still continues to entertain the art enthusiasts. Raghunath Chakravarty does not have any academic training. He did however found inspiration from his mother and later on from renowned Pot Chitro artist Shambhu Acharya. The stroke of the brush came to him naturally. "I learned from my mother. She used to paint Pot Chitro and decorate the house with alpona whenever there was an occasion, "he said." "From then on I had colors in my mind, I just started to compose in my head and started painting with a brush," Raghunath however personalized the art.

Attractive the lives of the ordinary folks, everyday struggle, "the beauty of the rural landscape", said Raghunath. Raghunath's favourite theme is the eternal love between mother and child. In his work the theme keep coming back along with boat race, the weavers and the carpenters at work, rural wife's cooking preparation, the bangles seller lady, women fetching water, ethnic women at work and many moves. Use of bright colors has always been a basic feature of the Pot Chitra, Raghunath did not manage this part vibrant colors red, orange, yellow, green, blue, deep purple brightened his creations.

Yellow is never brighter, red more festive, green more alive or blue more serene as they are in 'patachitra'. Patua Raghunath Chakroborty says, "Colors don't overlap in 'pata chitra', as in other mediums and styles. 'Patuas' (painters of this form) paint with locally produced vegetable colors, which not only make the scroll paintings very bright but also, add life to them." The scene apparently lasts over 50-60 years a remarkable feat for water color. Chakroborty has moved always from the traditional scroll style and put each scene on a single frame, giving it a contemporary feel while retaining its indigenous appeal; alongside religious themes, these works also highlight everyday events and people. Reghunath Chakroborty, originally from Gaibandha, has been living in Dhaka since 1992. A self-trained artist, Chakroborty did not go to any art school. The source of inspirations behind pursuing 'pata-chitra': Patua Shambhu Acharya. Why does he prefer this particular art form?" It's indigenous, inexpensive and its allure is uncomplicated. Materials like oyster shell powder, yellow squash, and gum made from tamarind seed and 'bel' (wood-apple) is easily available and I make my own brush for line-work Subjects are varied. The 'Pata-Chitra' at the exhibit features myths and deities like 'Janmashtomi', 'Sita', 'Lokkhi' as well as everyday scenes and objects like a lotus blossom, boatmen taking a break, a village belle putting her trinkets on, and the eternal.

\section{Folk Arts To Fashion Design}

We have seen and shown in the above that Bangladesh is profoundly sound in Folk arts .In some spaces it has very fundamental implications regarding the lifestyle, business, or the other modern activities in every sphere of the country. Here we have analysed the situations where folk arts are playing a very important role in the fashion context of the country. In the followings, we have got the scope to discuss about some of the organizations working in Bangladesh and working as flagships of the country especially for Fashion both exposure, marketing and its development. 


\section{AARONG}

In our country the major fashion house is Aarong which was developed with the aim to facilitate the marketing of the rural crafting goods so that then the Bangladesh rural people could be self employed after the liberation war of the country by Ayesa- Abed Foundation (one of the welfare project of BRAC). BRAC used to give the trainings and financial supports to its $V O$ (Village Organization) Members with opening of a marketing unit named Aarong in Dhaka. The main products of Aarong were Naksi Kantha, shetal pati (fine mat with one type of cane), potteries, toys, home textile, hand fans, showpieces, etc. Aarong successfully made the marketing with its good name inside the country even other parts of the world. Now, most all the necessary items are available in Aarong from garments, jewelries, crafting materials. The garments of Aarong have its own motifs which completely separated from others with its patent right. For example Aarong's motifs are: a Kantha in Bengali. A light quilted covering made from the old sharees / dhotis / lungis and sometimes from sheet cloths in large spread (Naksi Kantha in Bengali). An embellished quilt embroidered in traditional motifs and innovative style. Puja floor spread (Ashon in Bengali): Cloth spread for sitting at a place of worship or for an honored guest. Cosmetic wrapper (Arshilota in Bengali): A narrow embroidered wrapper to roll and store away a woman's comb, mirror, eye kohl, vermilion, sandal paste, oil bottle, etc. Often, a tying string is used to bind the wrap, as in was a practice in the past. Wallet: Small envelop shaped bag for keeping money, betel leaves, etc. Cover for the holy Quran (Ghilaf in Arabic and Bengali): Envelope shaped bag to cover the holy Quran. Prayer mats (Jainamaz in Bengali): Mats used by Muslims to say prayers. Floor spread (Galicha in Bengali): Floor covering. Cloths wrapper (Bostani, guthri in Bengali): A square wrapper for books and other valuables. Cover (Dhakni in Bengali): Covering cloths of various shapes and sizes. Ceremonial meal spread (Daster khan in Bengali): A spread for eating place, used at meal time. Pillow cover (Balisher chapa or oshar in Bengali): A flat single piece pillow cover. Handkerchief (Rumal): Small and square in shape. Modern fashion goods and home textiles: The newer uses are found for Nakshi Kanthas, such as bedspreads, wall hangings, cushion covers, ladies' purses, place mats, jeweler's boxes, dress fronts, skirts border and sharees.

Aarong has its different but own style not only in the motifs but colors, craftsmanship, decoration even in the fabric making with its specific design. On the other hand, the folk motifs mainly Kolka and its variations are being used by Aarong, which are popular its customers and well-wishers. By checking out their sharees to draw inspirations we get the colors such as, somber black and white, somber grey and zealous red. Moreover, the calligraphy motifs give the perfect expressions for Ekushey. We also get inspiring embellishments of block prints, screen prints, machine embroideries and geometrics on the elegant silk, half-silk, Muslin and cotton sharees. On the other hand, the Taaga collection offers a variety of fashionable attires. Relaxed and graceful, and harmonized with the passion of the juncture, the cotton outfits have tribal and folklore motifs in blacks, whites and reds. The shalwar-kameezes in grave black and white with hints of fervent red are the catch of the collection. With smart cuts, pockets and flairs, the long length kameezes are decorated with bold work of appliqué, tinsel, screen prints, cutworks, block prints and embroideries. The men's collection is not covering behind as well. Completed with symbolic colors, designs and Nakshi Kantha and calligraphy motifs, the panjabis reflect the zeal of Ekushey- of grief, pride and reverence.

\section{KUMUDINI CRAFT}

Kumudini Craft is famous for its creation with Bengal folk motifs. It has a wide range of craft products with folk motifs in Bangladesh and overseas. These products have their own excellent design and fine craftsmanship. Here the golden history of Bengal folk motifs and craftsmanship are reveled. We know that the story of Bangladeshi Handicrafts comes from one the oldest civilizations of the world. The enormous cultural and ethnic assortment has enabled a variety of motifs, techniques and crafts to flourish on this land.

Kumudni enjoys in-house facilities for the designing, sales, assembly and distribution of our products throughout the world. Its products are engraved out of the best quality raw materials and pass through severe quality tests at every stage of manufacturing with many floral, cultural even religious motifs. Its production unit is equipped with sophisticated tools and equipment with the skilled workers to develop, create or explore the folk motifs in the garments and other handicrafts. Kumudini Handicraft was established in 1980, particularly for the rural women. At present more than 25,000 artisans all over Bangladesh are able to earn their living through their association with. In order to have more manpower and engage a larger number of people all over Bangladesh, Kumudini Handicraft with the NGOs such Banchte Shekha, BRDB, Gono Unnayan Prochesta, Aranya, MCC, Save the Children Fund, World Vision Craft, HEED, Jagoroni and many others. Kumudini Handicraft's motto is to uplift the status both financial and social of Bangladeshi women, particularly of rural areas, by providing occasion for them to display ingenuity in craftsmanship under proper quality control and through their efforts to revive the traditional crafts and specialized textiles in Bangladesh.

Kumudini's variety of crafts include Nakshi Kantha, famous Jamdani and other fine textiles, endorsement of natural vegetable dyes, terracotta, ceramics, mats and basketry, wood and leather products among others. 
Kumudinis Motifs of the Nakshi Kantha are deeply influenced by religious belief and culture. Even though no specific strict symmetry is followed, a finely embroidered Naksi Kantha will always have a focal point. Most Nakshi Kanthas will have a lotus as focal point, and around the lotus there are often undulating vines or floral motifs, or a Sharee border motif. The motifs may include images of flower and leaves, birds and fish, animals, kitten forms even toilet articles.

While most Naksi Kantas have some initial pattern, no two Naksi Kantas are same. While traditional motifs are repeated, the individual touch is used in the variety of stitches, colors and shapes. The unique motifs found in Naksi Kantha and other garments, products of Kumudini are as follows:

The lotus motif is the most common motif found in Naksi Kanthas. This motif is associated with Hindu iconography and thus is also very popular in the Naksi Kantha. The lotus is the divine seat of God Krishna. It is also a symbol of cosmic harmony and essential womanhood. The lotus is also the symbol of eternal order and of the union of earth, water and, sky. It represents the life-giving power of water, and is also associated with the sun for the opening and closing of the petals. It is also the symbol of the recreating power of life. With the drying up of water, the lotus dies and with the rain it springs to life again. The lotus is associated with purity and the Goddess Laksmi, the Goddess of good fortune and abundance. There are various forms of lotus motifs, from the eight-petaled astadal padma to the hundred petaled satadal. In the older Naksi Kanthas, the central motif is almost always a fully bloomed lotus seen from above.

\section{Conclusion}

Bangladesh is rich by its cultural heritage in the context of it cultural heredity. Our curiosity knows no bound about Pot, Potua and Pot Music. Once Potua with a pot bag on the back of the shoulder used to visit houses and showing their pot started to sing to cool down the mind of the listeners. It was full of many charming histories of Ramayan, Mahabharat and Monsha and so on. The pot story thus created an enchanting lovely atmosphere of many romantic characters like, Sabitri-Shottoban, Ram-Sita-Rabon and Korno. From the birth of painting, we see that the artists were not related within a single profession. Rather, it was seen that they used to lead their life with multi professions. Implication of Folk arts in the fashion context is very vital in Bangladesh. Nowadays, Fashion industry is booming in this country as the nation is in swept in the globalization. There is huge scope that Bangladesh is the second largest garment manufacturing country world. Fashion can be richer by its new dimension mingled with the folk arts of Bangladesh.

\section{Books:}

\section{Bibliography}

[1] Ahmed. W. (2001) Banglar Loko Shanskriti, Goti Dhara, Dhaka.

[2] Ahmed. A. (1998) Gagir Gan: Shilpo Riti, Bangla Academy, Dhaka.

[3] Ghosh. P. Dr. (2004) Banglar Lokoshilpo , Okkhor Binnash, Dhaka.

[4] Guptto. S. Shankor (2010) Banglar Mukh Ami Dekhiashi, Bornaon, Dhaka.

[5] Hosson. D. (2009) Potua Roghu Nather Shilpo Bhubon, Bornaon, Dhaka.

[6] Islam. N. Mustafa (2001) Bangalir Attoporichoy, Bornaon, Dhaka.

[7] Islam. K. Dr. Prof. (2012) Adhunik Bangla Kobitar Loko Shongskritir Shorup Anneshon, Pranto Prokasion, Dhaka.

[8] Jhahan. A. Jahangir. (2012) Loko Vashar Suluk Shandhan, Shikha Prokashoni, Dhaka.

[9] Jhahan. A. Jahangir. (2011) Shangskar Lokachar Lokobishawsh, Mukto Chinta Prokashona, Dhaka.

[10] Lohani. K. (2010), Shanskritik Oaytijha Abong Nrittoshilpor Bistar, Ittadi, Dhaka.

[11] Morshed. M. Abul Kalam. (2011) Noboborsha o Banglar Loko Shongskritir, Shuci Potro, Dhaka.

[12] Moniruzzaman. Md. (2012) Bangladesher Itihash o Oitijha, Mizan Publisher, Dhaka.

[13] Mayti. C. Dr. (2001) Proshango: Pot, Potua o Potua Shangeet, Shahitto Lok, Calcutta.

[14] Phathan. M. Habibulla. (2012) Bangla probader Loko Kahini, Anindo Prokash, Dhaka.

[15] Raji. A. Alim (2010) Banglar Lokonattao Palagan: Prokriti o Proyog, Bangla Academy, Dhaka.

[16] Shom. S. (1993) Openti Bioscope, Camp, Calcutta.

[17] Shahed M. Sayed (2010) Foklor Shangrohosala, Bangla Academy, Dhaka.

\section{Web Sites:}

[18] Loving Bengal, Available from <http://sos-arsenic.net/lovingbengal/jasimuddin.html>, [Internet], [Accessed February 02, 2012]

[19] Sheindia, Available from <http://www.sheindia.org/news-events.html $>$, [Internet], [Accessed May 21, 2012]

[20] Rang-bd, Available from 〈http://www.rang-bd.com/>, [Internet], [Accessed May 21, 2012]

[21] Style, Available from<http://www.style.com.bd/2011/08/jatra-2011-eid-collection-elements/ $>$, [Internet], [Accessed May 21, 2012]

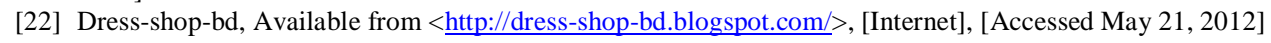

\section{Electronics Media:}

[23] Alpo Shalpo Golpo (2010), Episode 3, Subject: Gazir Pot, Duration: 14 Minutes 23 Second, Telecast: Desh TV. 